\title{
Factors Influencing a Public Health Centre Volunteers in Promoting Dengue Eradication Program
}

\author{
Lisa Efiana Malik \\ Faculty of Nursing Universitas Airlangga \\ Surabaya, Indonesia \\ Lisa.efiana.malik-2016@fkp.unair.ac.id \\ Makhfudli Makhfudli \\ Faculty of Nursing Universitas Airlangga \\ Surabaya, Indonesia \\ makhfudli@fkp.unair.ac.id
}

\author{
Setho Hadisuyatmana \\ Faculty of Nursing Universitas Airlangga \\ Surabaya, Indonesia \\ setho.h@fkp.unair.ac.id
}

\begin{abstract}
Dengue eradication program in Surabaya was far from success. It is arguable that this is because the volunteers who are responsible for promoting the programs did not do their best. Anecdotally, they were lack of knowledge, attitude, and skills in empowering the community to support the program. The purpose of this study was to explore the factors influencing their performance in empowering the community to implement the eradication program. This research used a cross-sectional approach. Sixty-four Dengue volunteers from 11 different subdistricts registered as participants by a proportional-clustered random sampling. Data were collected using modified questionnaires to explore the participants' knowledge, attitude, and performance. Data were then tested using a Spearman Rank test with the significance level of 0.05 . The results of this study imply that both knowledge and attitude have strong correlation with the performance in empowering the community $(p=0.0001$, $r=0.578$ and $p=0.0001, r=0.704$ in respective order) to promote a Dengue-free area. Despite the educational background, this study suggests that continuous development programs are beneficial to improve the work of the volunteers. On the other hand, this study highlights the importance of enhancing the awareness of the volunteers to gain their roles in dengue eradication program. Further research need to explore the level of volunteers' participation in training and health promotion efforts.
\end{abstract}

Keywords: knowledge, attitude, skills, dengue eradication, volunteer

\section{INTRODUCTION}

Key success factors of development of Dengue Hemorrhagic Fever prevention model in community level were making all sectors of the community to participate in all procedures, using of community stage, the mechanisms of the social application process [1]. Strategies should be developed to cultivate dengue prevention practices [2]. Under the Ministerial Decree Number 581 the year 1992, the Ministry of Health of the Republic of Indonesia to ensure that public health centres (Puskesmas) are allowed to hire volunteers (called as Jumantik) to support the works in eradicating the dengue health fever. The decree allows the Puskesmas to empower the volunteers to monitor dengue larvae within their neighbourhood, analysing and making a report of the larvae free index. In return, the Puskesmas are responsible for providing the Jumantik with supports and training to promote a dengue-free area. On the other hand, the Jumantik holds an important role in engaging the community within their work area to actively participating to suppress the population and, not to mention, the larvae and laying sites of mosquitoes [3].

However, the Department of Health of Surabaya (2014) reported that dengue remains as one of the prominent issues in public health. The department states that the disease routinely costs many patients every year, despite the dengue eradication program (PSN-DBD) firstly launched in late 1990's [4]. Like in the work area of PuskesmasTambak Wedi, one district in Northern Surabaya, it is reported that 8 cases found during the first three months of 2016. Further, the Jumantik report implied that this might be because the larvae free index was as low as $85 \%$.

It means that about $15 \%$ of the housing in Tambak Wedi was inhabited by dengue-vectors (Aedes sp.). Likewise, the PuskesmasRangkah, Eastern Surabaya, reported the same number of the case happened at the similar period. It was reported that the larvae free index in one area under the Puskesmas was as low as $62 \%$. This number was $33 \%$ lower than the targeted Index (95\%) to promote the dengue-free area [5]. However, the chairperson of the Communicable Disease and Environment Control at the Puskesmas Rangkah states that the number of the reported case was never accurate because of the tendency of the community to directly accessing the nearest hospitals rather than to make a prompt access to Puskesmas as the primary level of health facilities.

According to the pilot interviews, the community leaders confirm that they have been engaged in promoting the denguefree area. However, not all of the community members agree to participate in the PSN-DBD program. One of the leaders suggests that it may be because some of the Jumantik do not have sufficient understanding of the disease and the program when delivering health campaign. Further, prior investigation found that some of the Jumantik do not have the guideline book that should be available for all volunteers to support the 
conduct of the program. For instance, one of the volunteers worked in the Puskesmas Rangkah admitted that she was not provided with scheduled training other than only the logbook. As a consequence, she heavily relied on what she can get from other volunteers or other informal resources. Thus, her understanding was limited. These early findings suggest further investigation on their knowledge and attitude toward the program.

The larvae free index has long been the benchmark in predicting the incidence of Dengue Hemorrhagic Fever (DHF)[6]. The index also becomes the indicator for the dengue-vector density that also acts as the standard for evaluating the success of the PSN-DBD program [6]. This implies that the Jumantik and the community hold the same role in dengue eradicating actions and promoting dengue-free area [7]. The Department of Health Surabaya explained that the PSN-DBD program relies on the community active participation in maintaining the clean and larvae-free water supplies for families, protecting water container from mosquitoes laying eggs, reusing and recycling secondhand goods, and ensuring the surrounding environment free from mosquitoes (known as 3M-Plus movements) [4].

Knowledge, attitude, and skills are interrelated with the implementation of 3M-Plus movements. However, it does not clearly understandable that attitude and knowledge of the volunteers would influence their working performance [8]. This study aimed to gain further understanding of the aforementioned phenomenon.

On the other hand, the previous interview with several volunteers suggested that the Jumantik were never studied regarding their understanding and awareness, and their working performance related with the disease. This study aimed to give a voice for the volunteers in gaining supports from the Puskesmas and Department of Health. In further goals, this study aims to gain attentions from stakeholders to concern on DHF-free Health Promotion movements.

\section{MethodS}

This study used a cross-sectional design. According to Nursalam, this design allows a simultaneous data collection within a particular time [9]. One work area of a Puskesmas was intentionally selected under the consideration of its low percentage of the larvae free index. In further concern, the area was selected regarding the most reported incidence of DHF during the prior investigation related to this study.

Sixty-four out of 181 volunteers from 11 sub-districts under the Puskesmas registered as participants in this study. They were randomly selected through a proportional sampling counts (with a relative accuracy of $\mathrm{d}=0.1$ ). This method of sampling was selected to give account to representativeness value (see Table 1).
TABle 1. PARTICIPANT COUNT FOR EACH DisTRIC

\begin{tabular}{llllll}
\hline No & Sub-district & \multicolumn{1}{c}{ Count } & $\mathrm{n}$ \\
\hline 1. & I & 8 & $8: 181 \times 64$ & 3 & \\
2. & II & 4 & $4: 181 \times 64$ & 1 & \\
3. & III & 15 & $15: 181 \times 64$ & 5 & \\
4. & IV & 14 & $14: 181 \times 64$ & 5 & 31 \\
5. & V & 88 & $88: 181 \times 64$ & 3 & \\
6. & VI & 8 & $8: 181 \times 64$ & 2 & \\
7. & VII & 7 & $7: 181 \times 64$ & 2 & \\
8. & VIII & 8 & $8: 181 \times 64$ & 5 & \\
9. & IX & 7 & $7: 181 \times 64$ & 4 & \\
10. & X & 13 & $13: 181 \times 64$ & 64 & \\
11. & XI & 9 & $9: 181 \times 64$ & \\
\hline
\end{tabular}

The variables involved in this study were knowledge and attitude (independent variables) and volunteers' working performance in engaging communities in 3M-Plus movements (dependent variable). The data used in this study were collected through paper-based questionnaires adopted from previous research.

The questions asked in the questionnaire of this study have been tested for validity and reliability. The validity of each item was tested using the Pearson Correlation using the level of significance of 0.05 . The reliability of the items was tested using Cronbach Alpha.

The Human Research Ethic Committee granted the ethic of this study from the Faculty of Nursing Universitas Airlangga under the letter number 112-KEPK. Consent was offered to the potential participants before the questionnaires distribution. All of the 64-targeted participants replied and registered as sample to this study.

\section{RESULTS}

The routine works of the Jumantik as volunteers are to investigate the presence of mosquito larvae from door to door within their work area. This activity usually conducted once in a week. The local leader, as authorized person (later called as Ketua RW), recapitalizes the findings and report made by the Jumantik. The report is then submitted to the local Puskesmas as the main data for the monthly report required by the City Department of Health.

The Puskesmas is responsible for providing health education about PSN-DBD and 3M-Plus movements for the community if the finding suggests the necessity. This step is followed by the distribution of abate from the Puskesmas to the community through the assistance from the Jumantik.

The Jumantik responded to the calls of this study were all female, and mostly aged between 31 to 60 years old, worked as a housewife, and graduated from senior high school (See Table 2). 
TABLE 2. THE CHARACTERISTICS OF PARTICIPANTS

\begin{tabular}{ccc}
\hline Category & f & \% \\
\hline Age (y.o) : & 3 & \\
$21-30$ & 16 & 4,7 \\
$31-40$ & 23 & 25,0 \\
$41-50$ & 18 & 35,9 \\
$51-60$ & 4 & 28,1 \\
$61-70$ & & 6,2 \\
Occupation: & 2 & \\
Teacher & 54 & 3,12 \\
House wife & 1 & 84,3 \\
Pension & 7 & 1,56 \\
Part timer & & 11 \\
Bachelor & 7 & \\
High School & 35 & 11 \\
Secondary School & 14 & 54,7 \\
Primary School & 8 & 21,9 \\
Education: & & 12,5 \\
\hline
\end{tabular}

The initial analyses showed that most participants' knowledge and understanding about the disease and roles they carry were at least in average level (47\%). This finding also applies to the participants' attitude toward their roles and responsibilities as Jumantik (see Table 3)

TABle 3. Participants' KnOWLedge about Disease AND ATTITUDE' TOWARD THEIR ROLE AND RESPONSIBILITY IN DHF-3M PLUS MOVEMENT

\begin{tabular}{ccc}
\hline Category & f & \% \\
\hline Knowledge : & & \\
Fair & 17 & 26,5 \\
Average & 30 & 47 \\
Sufficient & 17 & 26,5 \\
Attitude: & & \\
Average & 27 & 42,19 \\
Sufficient & 37 & 57,81 \\
\hline
\end{tabular}

The statistical test of Spearman Rank to the tested variables shows that both knowledge and attitude have significant interrelations with the participants' working performance. Respectively, participants' knowledge has a sufficient interrelationship with their working.

The statistical test of Spearman Rank to the tested variables shows that both knowledge and attitude have significant interrelations with the participants' working performance. Respectively, participants' knowledge has a sufficient interrelationship with their working performance $(r=0.578)$, while their attitude strongly correlates with their work in promoting 3M-Plus movement ( $\mathrm{r}=0.704)$ (See Table 4). These findings suggest that the more participants have clear understanding and positive attitude toward the disease, the better health promotion effort they conduct.
TABLE 4. CROSS TABULATION OF INDEPENDENT VARIABLES AND DEPENDENT VARIABLE TO THE STUDY OF FACTOR InFLUENCING A PUblic HEALT CENTRE VOLUnTEERS IN PROMOTING DENGUE ERADICATION PROGRAM

\begin{tabular}{|c|c|c|c|c|}
\hline \multirow{2}{*}{ Knowledge } & \multicolumn{3}{|c|}{ Working Performance } & \multirow{2}{*}{ Total } \\
\hline & Fair & Moderate & Sufficient & \\
\hline \multirow[t]{2}{*}{ Poor } & 1 & 15 & 1 & 17 \\
\hline & $1.56 \%$ & $23.43 \%$ & $1.56 \%$ & $26.5 \%$ \\
\hline \multirow[t]{2}{*}{ Moderate } & 0 & 19 & 11 & 30 \\
\hline & $0 \%$ & $29.69 \%$ & $17.19 \%$ & $47 \%$ \\
\hline \multirow{2}{*}{ Sufficient } & 0 & 3 & 14 & 17 \\
\hline & $0 \%$ & $4.68 \%$ & $21.87 \%$ & $26.5 \%$ \\
\hline \multirow[t]{2}{*}{ Total } & 1 & 37 & 26 & 64 \\
\hline & \multicolumn{3}{|c|}{ Spearman Rank $\mathrm{p}=0.0001, \mathrm{r}=0.578$} & \\
\hline \multirow{2}{*}{ Attitude } & \multicolumn{3}{|c|}{ Working Performance } & \\
\hline & Fair & Moderate & Sufficient & Total \\
\hline \multirow[t]{2}{*}{ Moderate } & 1 & 26 & 0 & 27 \\
\hline & $1.56 \%$ & $40.6 \%$ & $0 \%$ & $42.19 \%$ \\
\hline \multirow[t]{2}{*}{ Sufficient } & 0 & 11 & 26 & 37 \\
\hline & $0 \%$ & $17.19 \%$ & $40.64 \%$ & $57.81 \%$ \\
\hline Total & 1 & 37 & 26 & 64 \\
\hline
\end{tabular}

\section{DISCUSSION}

Knowledge is one of the variables that comprise a personal selected behavior [10]. Knowledge level was significant factors associated with dengue prevention practice [11]. The components of knowledge researched in this study were the participants understanding in the etiology, methods of transmission, target, timing, mosquito breeding sites, sign and symptoms, complications, prevention, and grading of the DHF disease. These also include the correct timing and technique of PSN, the options for 3M-plus movements, and the use of abate powder.

The analysis of the item components implies that the participants' understanding of the necessity of fogging and on how to provide first aid for DHF patients were weak. This finding suggests that the Jumantik as volunteers may fail to understand their roles as mentioned in the DHF eradication guideline provided by the Ministry of Health [12]. This evidence reasons the community's low participation in PSN programs and 3M-Plus Movements. This finding further supports Green's [13] precede-proceed model, in which he proposes that sufficient knowledge is fundamental for intended behavior. Thus it highlights the need for capacity building programs for the volunteers, to enable them empowering the community. However, this study did not explore the participants' working performance when compared with other volunteers that have been trained properly.

Some of the suspected contributors that determine the volunteers' working performance and high-score when their knowledge was evaluated is their long-working experience. This finding suggests that the more frequent and longer the volunteer work to promote PSN, the better understanding they gain about the disease, the better work they can do [8]. This infers that the better the volunteers' understanding of their roles in PSN programs, the better work they perform. However, this study did not explore further the correlation between the 
volunteers' working experience and their understanding of the disease.

Notoatmodjo proposes that individuals will evaluate the stimulus they receive, and they both consciously and unconsciously select the behavior as the response [14]. This statement supports that the selected attitude toward the PSN programs will determine the volunteer's working performance [8]. The findings of this study suggest that the volunteers are less aware of their roles as Jumantik. Nevertheless, they perceive that it is important to ensure their work and responsibilities are carried well, which in turn improves their working satisfaction. This finding is inline with the Ahmad study that indicate strong positive relationship between job satisfaction and performance whereas organizational commitment has strong positive relation with performance and attitude towards work [15].

A further investigation to the volunteers shows that their working performance is fairly satisfactory and corresponding with the DHF eradication guideline provided by the Ministry of Health [12]. The working performance is not only affected by internal factors, but also by external factors. Saary \& Judge explains industrial/organizational psychology has a long, rich, and at times, controversial history related to the study and understanding of employee attitudes and job satisfaction. Future direction of employee attitude research will be to better understand the interplay between the person and the situation and the various internal and external factors that influence employee attitudes [16]

These findings conclude that the better understanding and perception of disease and responsibility as a volunteer is required to support the success of the PSN program. In turn, these elements contribute to the expected working performance of Jumantik as volunteers. Nevertheless, this study also highlights the needs for further research to find out other factors related to the working performance of volunteers.

\section{CONCLUSION AND RECOMMENDATION}

Continuous development programs are beneficial to improve the work of the volunteers. On the other hand, this study highlights the importance of enhancing the awareness of the volunteers to gain their roles in dengue eradication program.

The findings of this study suggest that capacity building programs are necessary for the Jumantik to support the expected outcomes of PSN and 3M-Plus movements, particularly to be able to provide first aid for DHF patients.

\section{REFERENCES}

[1] T. Khodmoungyod, "The Development Model of Dengue Hemorrhagic Fever Prevention in CommunityLevel, Srichompoo sub district ,Porncharoen district ,Buengkan Province,” J. Sakon Nakhon Hosp., vol. 17, no. 2, pp. 100-110, Jan. 2015.

[2] L. P. Wong, S. M. M. Shakir, N. Atefi, and S. AbuBakar, "Factors affecting dengue prevention practices: Nationwide survey of the Malaysian public," PLoS One, vol. 10, no. 4, pp. 1-16, 2015.

[3] Departemen Kesehatan Republik Indonesia, Pencegahan dan pemberantasan demam berdarah dengue di Indonesia. Jakarta: Departemen Kesehatan.Ditjen. Pengendalian Penyakit dan Penyehatan Lingkungan, 2005.

[4] Dinas Kesehatan Kota Surabaya, "Profil Kesehatan Kota Surabaya Tahun 2014," Surabaya, 2014.

[5] Departemen Kesehatan Republik Indonesia, Tatalaksana Deman Berdarah Dengue di Indonesia, 3rd ed. Jakarta: Direktorat Jenderal Pemberantasan Penyakit Menular dan Penyehatan Lingkungan Departemen Kesehatan Republik Indonesia, 2004.

[6] Departemen Kesehatan Republik Indonesia, Pedoman survei entomologi demam berdarah dengue. Jakarta: Direktorat Jenderal Pengendalian Penyakit dan Penyehatan Lingkungan Departemen Kesehatan Republik Indonesia, 2007.

[7] N. S. Yulianti, "Pengaruh keaktifan Juru Pemantau Jentik (Jumantik) terhadap Angka Bebas Jentik (ABJ) dan kejadian Demam Berdarah Dengue (DBD): Studi pada pelaksanaan Gerakan Jumat Berseri + PSN 60 menit" di Kota Mojokerto," Universitas Airlangga, 2007.

[8] Rosdiana, "Hubungan Pengetahuan, Sikap dan Perilaku dengan Pemberantasan Sarang Nyamuk DBD di RT. 02 Desa Loa Janan Ulu Puskesmas Loa Janan Kutai Kertanegara Kalimantan Timur," Universitas Sebelas Maret, 2010.

[9] Nursalam, Konsep Penerapan Metode Penelitian Ilmu Keperawatan. Jakarta: Salemba Medika, 2013.

[10] S. Notoatmojo, Promosi Kesehatan dan Perilaku Kesehatan. Jakarta: Rineka Cipta, 2012.

[11] J. R. Chandren, L. P. Wong, and S. AbuBakar, "Practices of dengue fever prevention and the associated factors among the Orang Asli in Peninsular Malaysia," PLoS Negl. Trop. Dis., vol. 9, no. 8, pp. 1$17,2015$.

[12] Departemen Kesehatan Republik Indonesia, Petunjuk teknis pemberantasan sarang nyamuk Demam Berdarah Dengue (PSN DBD) : oleh juru pemantau jentik (Jumantik). Jakarta: Direktorat Jenderal Pengendalian Penyakit dan Penyehatan Lingkungan Departemen Kesehatan Republik Indonesia, 2012.

[13] L. Green and M. W. Kreuter, The precede-proceed model. Health promotion planning: an educational approach, 3rd ed. Mountain View (CA): Mayfield Publishing Company, 1999.

[14] S. Notoatmojo, Pendidikan dan Perilaku Kesehatan. Jakarta: Rineka CIpta, 2003.

[15] H. Ahmad, K. Ahmad, and I. Ali Shah, "Relationship between Job Satisfaction, Job Performance Attitude towards Work and Organizational Commitment," Eur. J. Soc. Sci., vol. 18, no. 2, pp. 257-267, 2010.

[16] L. M. Saari and T. A. Judge, "Employee attitudes and job satisfaction," Hum. Resour. Manage., vol. 43, no. 4, pp. 395-407, 2004. 